\title{
Impact of Substrate Volumetric Water on Pythium aphanidermatum Infection in Petunia xhybrida: A Case Study on the Use of Automated Irrigation in Phytopathology Studies
}

\begin{abstract}
William D. Wheeler, Department of Horticulture; Jean Williams-Woodward, Department of Plant Pathology; Paul A. Thomas, Marc van lersel, and Matthew R. Chappell, Department of Horticulture, University of Georgia, Athens 30602
\end{abstract}

Accepted for publication 15 May 2017.

\section{Abstract}

Real-time irrigation monitoring and control afforded by dielectric soil moisture sensors allows for precise substrate volumetric water content (VWC) to be maintained under dynamic experimental conditions. A case study was conducted with Petunia xhybrida 'Dreams Red' grown using a sensor-based irrigation system with half of the plants infected with Pythium aphanidermatum. Four soilless substrate moisture profiles were maintained postinoculation, with VWCs set at $0.2,0.3$, and $0.4 \mathrm{~m}^{3} / \mathrm{m}^{3}$, as well as a cyclic soil moisture profile that underwent a $0.25-\mathrm{m}^{3} / \mathrm{m}^{3}$ change in VWC $(0.18$ to $0.43 \mathrm{~m}^{3} / \mathrm{m}^{3}$ ) between irrigation events. Once established, half of the plants in each trial were inoculated and grown out for one month under the defined irrigation regimes. The probability of root infection was lowered when VWC was maintained at $0.2 \mathrm{~m}^{3} / \mathrm{m}^{3}$ compared with $0.4 \mathrm{~m}^{3} / \mathrm{m}^{3}$ and cyclic $\left(0.18\right.$ to $\left.0.43 \mathrm{~m}^{3} / \mathrm{m}^{3}\right)$ VWC. Mortality and biomass were unaffected by irrigation regime in both uninoculated and inoculated treatments. The soil moisturesensor-based automated irrigation system was successfully able to maintain programmed irrigation profiles throughout the trial, under dynamic greenhouse conditions, increasing trust in the data and resulting conclusions of the study.

\section{Mission Statement}

This research was conducted to serve as a case study for how researchers can utilize newly developed and commercially available automated irrigation technologies to improve the precision and accuracy of soil VWC measurement and subsequent irrigation control in phytopathology research. In this study, dielectric soil moisture sensors were utilized to automate irrigation control, based on user-defined substrate VWC profiles. These types of systems have been demonstrated to maintain substrate VWC within a very narrow window (Nemali and van Iersel 2006), allowing for accurate control of soil moisture profiles that result in more reliable correlations among root-pathogen infection and root-zone edaphic conditions.

\section{Irrigation Practices and Susceptibility to Root Pathogens}

Oomycetes are prevalent plant pathogens, affecting ornamental, food, and fiber crops worldwide. Previous phytopathology studies have indicated that prolonged root-zone saturation, maintained at or near field capacity, increases the incidence and severity of root infections in a number of plant species (Elmer et al. 2012; Hancock 1990; Wilcox and Mircetich 1985). Conversely, drought stress experienced before inoculation with Phyotphthora spp. has been shown to increase the severity of visible disease symptoms and to decrease root weights (Duniway 1977). Blaker and MacDonald (1981) reported that root-zone moisture extremes, both drought stress and saturated conditions, were shown to predispose normally resistant taxa to root and crown rots from Phytophthora spp. Based on prior

Corresponding author: Matthew R. Chappell; E-mail: hortprod@uga.edu

(C) 2017 The American Phytopathological Society

results, it is hypothesized that cyclic moisture profiles, such as those created by traditional timer-based irrigation management of potted ornamental plants, may introduce greater stress and as a result reduce crop resilience to root pathogens (Biesbrock and Hendrix 1970).

The importance of employing irrigation practices that minimize disease incidence and severity is directly related to the economic sustainability of commercial growing operations. Damage and control costs from root and crown rots in the state of Georgia alone were estimated to account for a $4.0 \%$ reduction in the farm gate value of ornamental crops in 2013 (Martinez-Espinoza 2013). Given that the market value of nursery, greenhouse, and floriculture crops grown in the United States was estimated to be $\$ 18.5$ billion in 2012 (USDA-NASS 2013), similar reductions from crown and root rots nationally could account for $\$ 740$ million in losses. Within the genera of Pythium and Phytophthora, the most common and destructive oomycete pathogens, partial or complete resistance to a number of fungicides has been reported (Lookabaugh et al. 2015; Moorman et al. 2002). It is therefore important to develop or improve upon existing nonchemical control measures for these pathogens. Doing so should lead to reduced reliance on fungicidal treatments, thereby preventing or delaying resistance development. Better irrigation control is also a cost-effective and environmentally friendly means of minimizing disease prevalence through modification of the growing environment.

The use of dielectric soil moisture sensors are an effective means to automate irrigation in both controlled physiology studies and applied case studies in commercial horticultural operations (Belayneh et al. 2013; Chappell et al. 2013; Lea-Cox et al. 2013; van Iersel et al. 2009). Dielectric sensors take advantage of the high dielectric constant of water and relatively low dielectric constant of soil or soilless substrate to determine VWC. These types of sensor-based 
irrigation systems have been demonstrated to be able to monitor and maintain moisture contents within 3\% of programmed VWC thresholds over an entire crop cycle (Nemali and van Iersel 2006). Previous phytopathology studies have relied on laboratory methods, or infield devices such as tensiometers or lysimeters to make determinations of when manual irrigations are necessary (Bernhardt and Grogan 1982; Bowers and Mitchell 1990; Sterne et al. 1977). The increased control over root zone conditions, while producing plants in either a greenhouse or field setting with sensor-based irrigation, could improve reliability and repeatability of studies of root pathogens. Anecdotal observations from case studies have suggested a relationship between the use of soil moisture-sensorbased automated irrigation and a reduction in crop losses due to disease in a commercial nursery (Chappell et al. 2012). To the best of our knowledge, no studies have been carried out examining the use of dielectric sensor-based automated irrigation systems to control VWC, or the associated impact on oomycete root pathogen infection.

\section{Design of Automated Irrigation System and Soil Moisture Profiles}

The soil moisture sensor-based automated irrigation system used in this study was designed based on a system originally described by Nemali and van Iersel (2006) and commercially available through several companies such as Decagon Devices, Inc. and Acclima, Inc. A total of 32 irrigation zones were fabricated, each with one corresponding soil moisture sensor (EC-5; Decagon Devices, Pullman, WA). Each sensor was inserted at a $45^{\circ}$ angle into the center of a representative single-plant-containing pot per irrigation line. Soil moisture sensors were connected to a multiplexer (AM16/32B; Campbell Scientific, Logan, UT) that was in turn connected to a data logger (CR10X; Campbell Scientific), which recorded voltage output readings from the soil moisture sensors every $10 \mathrm{~s}$. The data logger converted voltage readings to VWC using a substratespecific calibration equation [VWC $=1.13 \times(\text { voltage })^{2}-0.612 \times$ voltage +0.0889 ]. Two relay drivers (SDM-CD16AC/DC; Campbell Scientific) were connected to the data logger to control 32 solenoid irrigation valves (075-DV 3/4-inch; Rain Bird, Azusa, CA), one for each irrigation line. Four irrigation treatments were chosen for the purpose of this experiment. Three irrigation treatments maintained soil moisture contents near threshold VWC's of $0.2,0.3$, and $0.4 \mathrm{~m}^{3} / \mathrm{m}^{3}$ (corresponding to dry, moderate, and wet substrates) and one irrigation treatment cycled between 0.18 and $0.43 \mathrm{~m}^{3} / \mathrm{m}^{3}$, resulting in a change of $0.25 \mathrm{~m}^{3} / \mathrm{m}^{3}$ in VWC between irrigation events (Fig. 1). These low and high setpoints were chosen as they corresponded to water contents just above the wilting point of our experimental taxa (Petunia xhybrida; Kim et al. 2011) and at the field capacity of the substrate. When sensor readings fell below VWC thresholds, the relay driver powered the corresponding solenoid valve, irrigating the crop until VWC readings exceeded the programmed threshold. Each pot was irrigated with dribble rings (DR6; Dramm, Manitowoc, WI) that were $10 \mathrm{~cm}$ in diameter. Dribble rings were connected to pressure-compensated drip emitters rated at 2 liters/h (PCJ; Netafim USA, Fresno, CA).

\section{Experimental Arrangement}

All experiments carried out in this study, including irrigation system set-up as well as plant growth and inoculation, were carried out at the University of Georgia horticulture greenhouse complex in Athens, GA $\left(33^{\circ} 55^{\prime} 50.9^{\prime \prime} \mathrm{N}, 83^{\circ} 21^{\prime} 50.4^{\prime \prime} \mathrm{W}\right)$. The experimental design was a randomized complete block with eight treatments, four replications, and four plants per experimental unit. Two duplicate trials, conducted sequentially, ran for four weeks each. The first trial

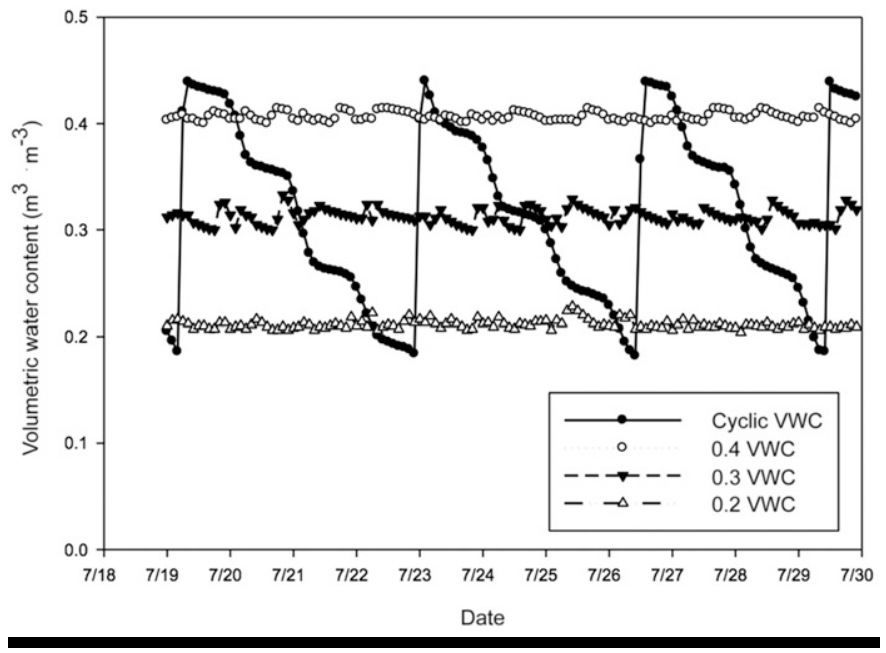

FIGURE 1

Soil moisture sensor readings over a 12-day period from 19 to 30 July 2015 for the sensor-based automated irrigation system. The sensor-based automated irrigation system maintained substrate volumetric water content (VWC) at $0.2,0.3$, and $0.4 \mathrm{~m}^{3} / \mathrm{m}^{3}$ as well as created a cyclic soil moisture profile, allowing substrate to dry down to $0.18 \mathrm{~m}^{3} / \mathrm{m}^{3}$ before irrigating to $0.43 \mathrm{~m}^{3} / \mathrm{m}^{3}$. The automated irrigation system received readings from soil moisture sensors every $10 \mathrm{~s}$ and opened or closed the corresponding solenoid valve dependent upon if readings fell above or below the programmed threshold. Substrate moisture readings were averaged over 2-h periods.

began on 8 July 2015 and the second on 1 September 2015. Each trial examined four soil moisture profiles, under either inoculated or uninoculated conditions. Both trials consisted of a total of 128 Petunia $\times$ hybrida 'Dreams Red' seedlings transplanted from 128cell plug trays into individual pots with one plant per pot. Seedlings were purchased from C. Raker \& Sons, Inc. for the trial conducted in July and produced on site for the trial conducted in September. Plastic opaque pots $(10 \mathrm{~cm}$ diameter $\times 16 \mathrm{~cm}$ height $)$ were loosely filled with 1 liter of a peat and perlite based potting substrate. The July trial utilized a substrate blend of $65 \%$ peat and $35 \%$ perlite (Fafard 1P; Sun Gro, Agawam, MA) while the September trial utilized a similar substrate blend of $80 \%$ peat and $20 \%$ perlite (Fafard 2P; Sun Gro). In both trials, the substrate was amended with 14-14-14 Osmocote Classic (Everris Inc., Dublin, OH) fertilizer at a rate of $5.0 \mathrm{~kg} / \mathrm{m}^{3}$. All pots were hand watered for 14 days after transplanting to allow for individual seedling establishment within the pot. Greenhouse night temperature was maintained at $29.4^{\circ} \mathrm{C} \pm$ $2.1^{\circ} \mathrm{C}$ and daytime temperature maintained at $35.0^{\circ} \mathrm{C} \pm 3.2^{\circ} \mathrm{C}$.

\section{Inoculum Preparation and Treatment Assesment}

Pythium aphanidermatum (Edson) Fitzp. (isolate 'M15D'), originally recovered from symptomatic Euphorbia pulcherrima cultivated in Georgia and previously determined to be pathogenic on petunia (J. Williams-Woodward, unpublished data), was used for this study. The isolate was maintained using the protocol outlined by Jeffers and Martin (1986). Inoculum was prepared by filling 1000-ml Erlenmeyer flasks with $500 \mathrm{ml}$ vermiculite mixture comprised of $500 \mathrm{ml}$ fine vermiculite (Sta-Green; Sun Gro); $25 \mathrm{~g}$ of plain yellow corn meal (House-Autry, Four Oaks, NC); and $250 \mathrm{ml}$ V8 broth $\left(200 \mathrm{ml} \mathrm{V8}\right.$ juice, $2 \mathrm{~g} \mathrm{CaCO}_{3}$, and $800 \mathrm{ml}$ deionized water). Flasks were plugged with foam stoppers, covered with aluminum foil, and autoclaved twice for $60 \mathrm{~min}$ at $121^{\circ} \mathrm{C}$ over two consecutive days. Ten 5-mm-diameter mycelial plugs from 1-week-old 
$P$. aphanidermatum cultures were aseptically transferred to each flask and gently shaken to distribute the plugs within the vermiculite mixture. Flasks were incubated under diffuse light at room temperature $\left(22^{\circ} \mathrm{C}\right)$ for 2 days, gently shaken to break up and distribute mycelium, and incubated for an additional 5 days prior to use in greenhouse trials. In the greenhouse, a glass rod was used to create two 5-cm-deep holes in the rooting substrate of each plant for insertion of inoculum. Each hole was $5 \mathrm{~cm}$ from the pot wall and adjacent to the plug root ball. In a preliminary trial, $36 \mathrm{ml}$ of colonized vermiculite was distributed between the two holes in each pot and recovered with substrate. Extensive mortality in this preliminary trial was noted across all treatments in under $24 \mathrm{~h}$. For this reason, in both of the reported trials, $18 \mathrm{ml}$ of colonized vermiculite was determined to provide significant disease pressure without causing rapid and widespread mortality. All pots were maintained at saturation for $24 \mathrm{~h}$ postinoculation to assure substrate colonization of $P$. aphanidermatum prior to reinstituting irrigation treatments.

Mortality was tracked for each treatment combination and percent mortality was calculated based on the number of plants that died in each treatment combination over the course of both trials. At the end of each trial, all plants were cut at the soil line and the canopy dried for $72 \mathrm{~h}$ at $85^{\circ} \mathrm{C}$, then weighed to determine dry shoot weight. Roots were washed to remove attached substrate, dried for $72 \mathrm{~h}$ at $85^{\circ} \mathrm{C}$, and weighed to determine dry root weight. Approximately four grams of fresh roots were collected from each treatment combination, one gram from each subreplicate, prior to root washing and stored in a refrigerator at $5^{\circ} \mathrm{C}$ until processing within 1 to 2 weeks. Root subsamples were gently washed under running water and 20 one-centimeter root sections were randomly excised and embedded into V8 PARP medium. Embedded root sections were then incubated under diffuse
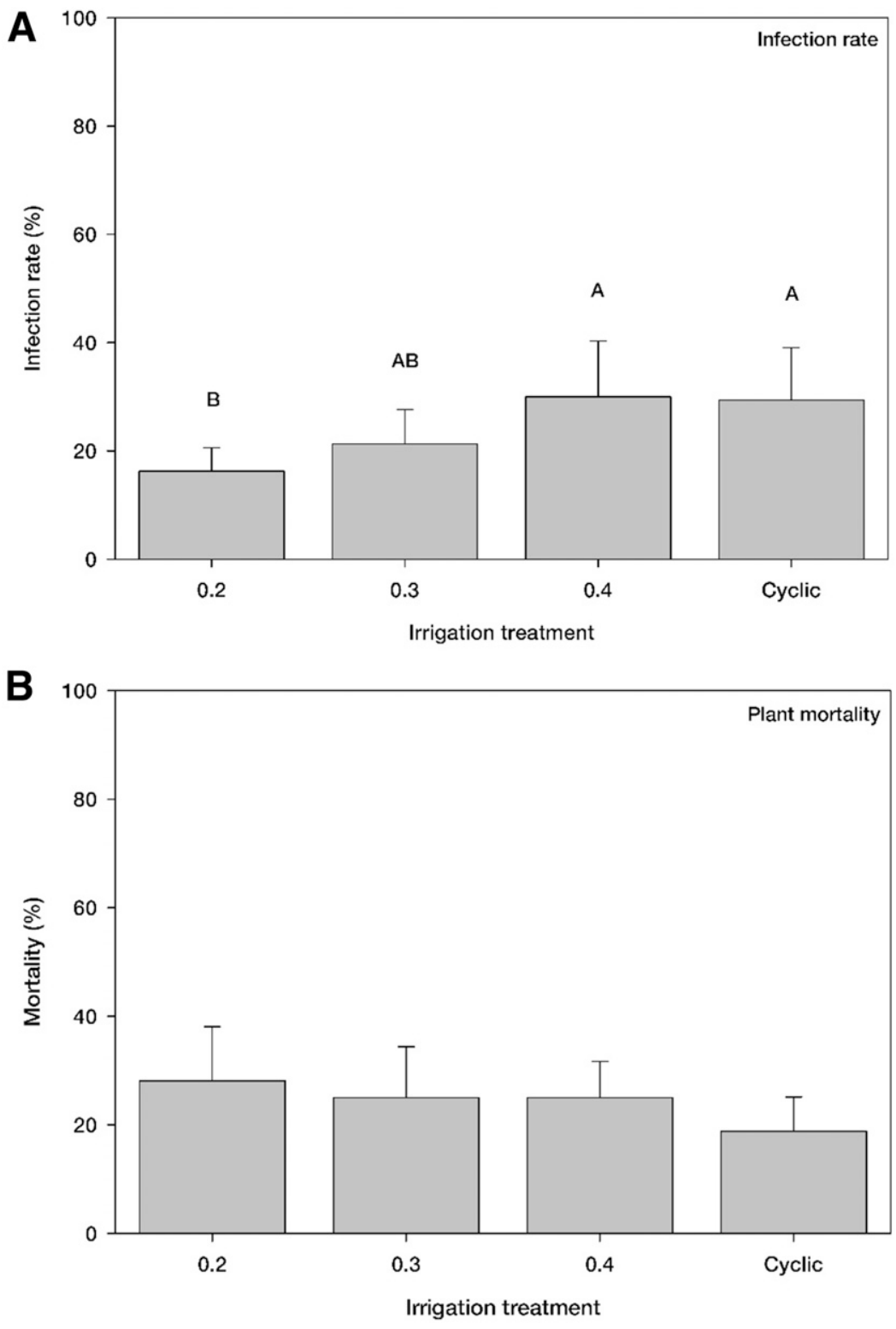

FIGURE 2

Pythium aphanidermatum root infection rate $(\mathbf{A})$ and plant mortality $(\mathbf{B})$ in inoculated Petunia $\times$ hybrida 'Dreams Red'. Irrigation treatments were imposed using a soil moisture-sensor-based automated irrigation system to maintain volumetric water contents of the soilless substrate at $0.2,0.3$, and $0.4 \mathrm{~m}^{3} / \mathrm{m}^{3}$ as well as creating a cyclic soil moisture profile, allowing substrate to dry down to $0.18 \mathrm{~m}^{3} / \mathrm{m}^{3}$ before irrigating to $0.43 \mathrm{~m}^{3} / \mathrm{m}^{3}$. 
fluorescent light at room temperature $\left(22^{\circ} \mathrm{C}\right)$ for $48 \mathrm{~h}$ before being examined microscopically for the presence of $P$. aphanidermatum hyphal structures. Infection rate was determined by comparing the number of root pieces from which $P$. aphanidermatum growth was observed to the total number of root pieces plated. Observed hyphal growth was subcultured onto V8 PARP medium and incubated at room temperature $\left(22^{\circ} \mathrm{C}\right)$ for seven days prior to pathogen confirmation. The presence of $P$. aphanidermatum from cultured root sections was confirmed through amplification of the internal transcribed spacer (ITS) region using primers ITS1 and ITS4. A protocol modified from the UCLA Barber Ecology and Evolutionary Biology Laboratory (UCLAEEB 2004; White et al. 1990) was used for pathogen DNA extraction.

\section{Comparison of Soil Moisture Profiles}

Differences among substrate moisture profiles and the impact of inoculation were analyzed utilizing SAS v. 9.4 (SAS Institute Inc., Cary, NC). All analyses used PROC GLIMMEX and treated trial replicates as a random effect while irrigation and pathogen inoculation were treated as fixed effects. Data from both trials were combined and no differences in experimental variables were noted between trials, allowing for trials to be analyzed as a single dataset. In both trials, root infection and whole plant mortality were noted only in inoculated treatments. Within inoculated treatments, plants maintained at a VWC of $0.2 \mathrm{~m}^{3} / \mathrm{m}^{3}$ had average root infection rates of $16 \pm 4 \%$ (SE). This was significantly lower than plants

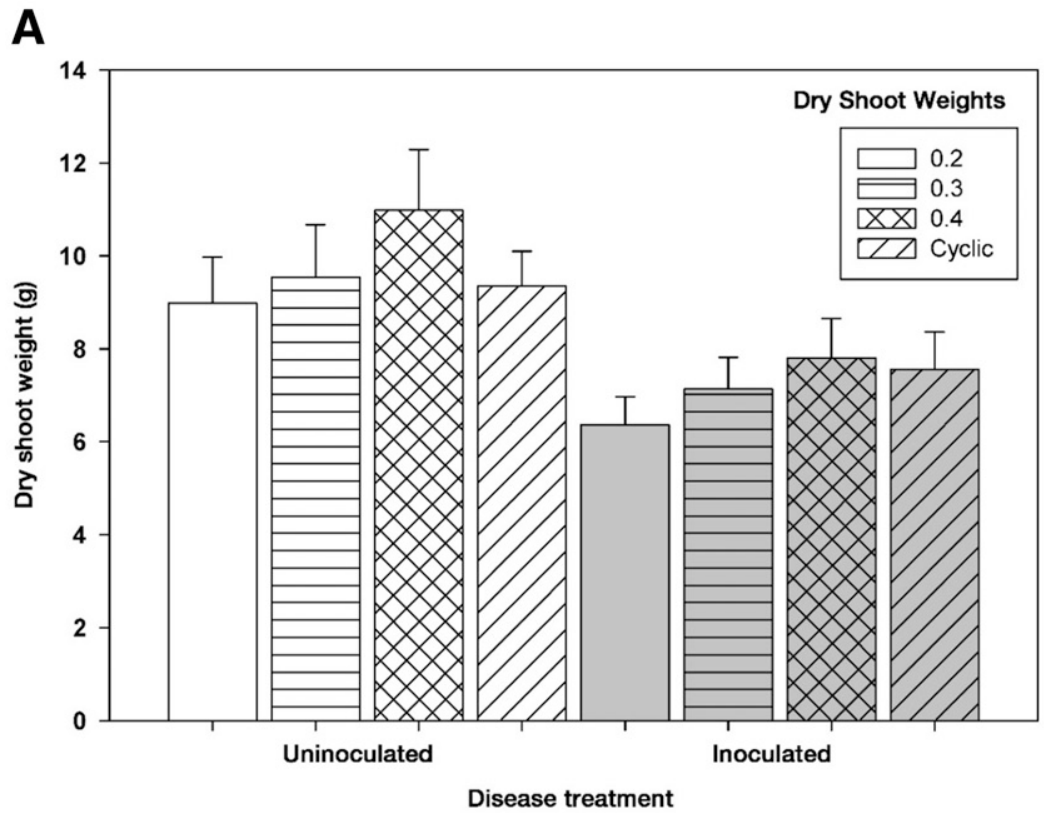

B

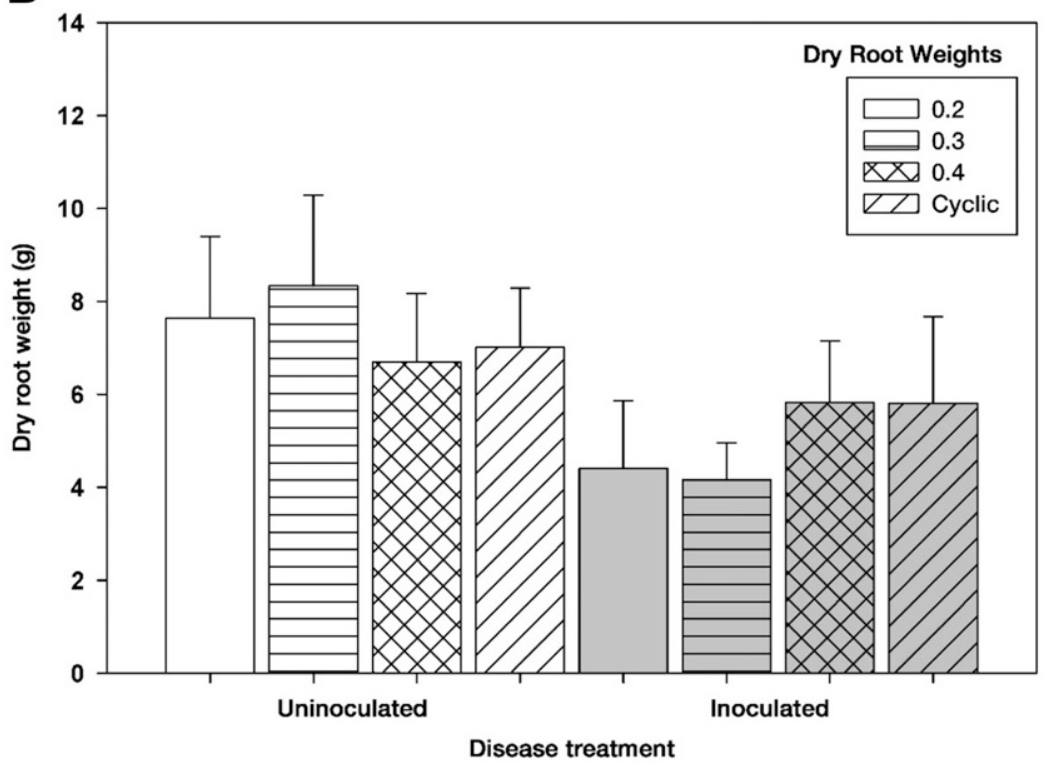

FIGURE 3

Shoot (A) and root (B) dry weights of Petunia xhybrida 'Dreams Red' in uninoculated and inoculated treatments (with Pythium aphanidermatum). The sensorbased automated irrigation system maintained substrate volumetric water content (VWC) at $0.2,0.3$, and $0.4 \mathrm{~m}^{3} / \mathrm{m}^{3}$ as well as created a cyclic soil moisture profile, allowing substrate to dry down to $0.18 \mathrm{~m}^{3} / \mathrm{m}^{3}$ before irrigating to $0.43 \mathrm{~m}^{3} / \mathrm{m}^{3}$. 
maintained at $0.4 \mathrm{~m}^{3} / \mathrm{m}^{3}(P=0.02)$ and under cyclic VWC $(P=$ $0.03)$, which had infection rates of $30 \pm 10 \%$ and $29 \pm 9 \%$, respectively (Fig. 2). Root infection rates of plants grown at consistent VWC of $0.3 \mathrm{~m}^{3} / \mathrm{m}^{3}$ was $21 \pm 6 \%$, which did not differ from infection rates in any other treatment. Differences in plant mortality, while not significant $(P=0.88)$, had the opposite trend observed for root infection (Fig. 2). Inoculated plants grown at $0.2,0.3$, and $0.4 \mathrm{~m}^{3} / \mathrm{m}^{3}$ incurred $28 \pm 10 \%, 25 \pm 9 \%$, and $25 \pm 6 \%$ mortality, respectively, while inoculated plants grown with cyclic irrigation incurred $18 \pm 6 \%$ mortality. Consequently, there was no correlation between infection rate and plant mortality $(P=0.19)$.

Inoculation with $P$. aphanidermatum reduced dry root and shoot weight $(P<0.01)$ across all irrigation treatments by an average of $2.37 \pm 0.79 \mathrm{~g}$ and $2.50 \pm 0.29 \mathrm{~g}$, respectively (Fig. 3). No interactive effect between irrigation treatment and inoculation was noted in either root $(P=0.29)$ or shoot $(P=0.72)$ dry weight. Irrigation treatments had no effect on dry root weights within the uninoculated $(P=0.90)$ and inoculated treatments $(P=0.76)$. Dry root weights ranged from $6.70 \pm 1.47 \mathrm{~g}$ to $8.34 \pm 1.95 \mathrm{~g}$ in the uninoculated treatments and $4.17 \pm 0.79 \mathrm{~g}$ to $5.82 \pm 1.32 \mathrm{~g}$ in the inoculated treatments. Similarly, shoot dry weight was unaffected by irrigation treatment in both the uninoculated $(P=0.56)$ and inoculated treatments $(P=0.54)$. Dry shoot weights ranged from $8.99 \pm 0.98 \mathrm{~g}$ to $10.99 \pm 1.30 \mathrm{~g}$ in the uninoculated treatments, and from $6.36 \pm$ $0.61 \mathrm{~g}$ to $7.80 \pm 0.85 \mathrm{~g}$ in inoculated treatments.

\section{Findings and Future Opportunities}

Previous research has shown that both abundant soil moisture and cyclic drying and wetting of substrate can promote root pathogen proliferation, growth, and subsequent primary and secondary infections (Blaker and MacDonald 1981; Martin and Loper 1999). Conversely, $P$. aphanidermatum oospore germination and germ tube growth is reduced in consistently dry soil conditions (Stanghellini and Burr 1973). Data from this study indicated that maintaining consistently dry root zone conditions $\left(0.2 \mathrm{~m}^{3} / \mathrm{m}^{3}\right)$ lowered root infection rates within inoculated treatments when compared with substrates maintained near saturation $\left(0.4 \mathrm{~m}^{3} / \mathrm{m}^{3}\right)$ and those undergoing cyclic wetting and drying $\left(0.18\right.$ to $\left.0.43 \mathrm{~m}^{3} / \mathrm{m}^{3}\right)$. This is consistent with other research that found disease incidence in soybean (Glycine max [L.] Merr.) correlated positively with the number of days with high soil-water matric potential (Schlub and Lockwood 1981). It is also consistent with findings of increased root necrosis caused by Pythium spp. on holly (Illex crenata 'Helleri') grown under cyclic soil-water availability (Biesbrock and Hendrix 1970). However, reductions in root infection rates did not correspond to a decrease in plant mortality, which averaged $24 \pm 8 \%$ over all inoculated irrigation treatments in this study (Fig. 2). It is hypothesized that the inoculation method used may have contributed to the observed results. To ensure infection, all treatments were irrigated to field capacity $\left(0.43 \mathrm{~m}^{3} / \mathrm{m}^{3}\right)$ immediately following inoculation and maintained at field capacity for $24 \mathrm{~h}$ before implementing irrigation treatments that were maintained throughout the remainder of the experiment. Doing so ensured the pathogen's distribution from the vermiculite carrier into the substrate. Once irrigation treatments were implemented, it took an average of $48 \mathrm{~h}$ for the $0.30 \mathrm{~m}^{3} / \mathrm{m}^{3}$ treatment and $90 \mathrm{~h}$ for the $0.20 \mathrm{~m}^{3} / \mathrm{m}^{3}$ treatment to reach and stabilize at the respective VWC treatment levels. We hypothesize that maintaining VWC at field capacity for $24 \mathrm{~h}$ after inoculation resulted in primary, or hyphal, infection of plants in all irrigation regimes. In the driest treatment, where plants were under mild water stress, the combined pressure of primary $P$. aphanidermatum infection and drought stress may have led to higher levels of plant mortality than expected, similar to results summarized by Schoeneweiss (1978). However, lower root infection rate in the driest treatment suggests that secondary infection may have been reduced by the dry substrate conditions.

No significant differences were seen in biomass among any of the irrigation treatments. While the presence of $P$. aphanidermatum caused reductions in dry shoot weight, none of the irrigation treatments significantly mitigated the negative impacts of inoculation with the root pathogen. It is hypothesized that, prior to pathogen introduction, implementation of substrate moisture profile(s) that are not conducive to pathogen development yet favorable for plant growth could disrupt pathogen establishment while not impacting plant biomass or mortality. Based on results presented in this study, integrated pest management recommendations could be expanded to include maintaining consistently dry, yet stable VWC to prevent the primary infection (establishment) and secondary infection (spread) of Pythium spp. This, combined with sanitation practices, could significantly reduce disease incidence, severity, and spread in many crops.

This study documents the first use of a dielectric soil moisturesensor-based irrigation system in a phytopathology study; results indicate the experimental design offers more clarity via an ability to restrict soil VWC to within $3 \%$ of VWC setpoint(s). Over the course of the study the sensor-based automated irrigation system was able to successfully control irrigation in response to dynamic greenhouse environmental conditions. The overall design of the system was such that it could easily be modified to accommodate a wide variety of research settings and could be established in a laboratory, greenhouse, or field. This system, which can be commercially obtained, allows for reduced labor inputs while improving the precision of soil moisture control and can be programmed to produce a wide variety of soil moisture profiles. These advantages could provide plant pathologists greater flexibility, accuracy, and repeatability to explore how root zone environmental conditions affect disease development and spread.

\section{Acknowledgments}

This research was sponsored by a USDA Specialty Crop Block Grant administered by the Georgia Department of Agriculture. This paper is a portion of a thesis submitted by the first author in fulfilling a degree requirement.

\section{Literature Cited}

Belayneh, B. E., Lea-Cox, J. D., and Lichtenberg, E. 2013. Costs and benefits of implementing sensor-controlled irrigation in a commercial pot-in-pot container nursery. HortTechnology 23:760-769.

Bernhardt, E. A., and Grogan, R. G. 1982. Effect of soil matric potential on the formation and indirect germination of sporangia of Phytophthora parasitica, Phytophthora capsici, and Phytophthora cryptogea. Phytopathology 72: 507-511.

Biesbrock, J. A., and Hendrix, F. F., Jr. 1970. Influence of continuous and periodic soil water conditions on root necrosis of holly caused by Pythium spp. Can. J. Bot. 48:1641-1645.

Blaker, N., and MacDonald, J. 1981. Predisposing effects of soil moisture extremes on the susceptibility of rhododendron to Phytophthora root and crown rot. Phytopathology 71:831-834.

Bowers, J. H., and Mitchell, D. J. 1990. Effect of soil-water matric potential and periodic flooding on mortality of pepper caused by Phytophthora capsici. Phytopathology 80:1447-1450.

Chappell, M., Dove, S. K., van Iersel, M. W., Thomas, P. A., and Ruter, J. 2013. Implementation of wireless sensor networks for irrigation control in three container nurseries. HortTechnology 23:747-753.

Chappell, M., van Iersel, M., Lichtenberg, E., Majsztrik, J., Thomas, P., Ruter, J., and Wells, S. 2012. Benefits of precision irrigation of Gardenia augusta "Heaven Scent": Reducing shrinkage, shortening the cropping cycle, and economic impact. Proc. Southern Nursery Assn. Res. Conf. 57:321-323. 
Duniway, J. 1977. Predisposing effect of water stress on the severity of Phytophthora root rot in safflower. Phytopathology 67:884-889.

Elmer, W., Gent, M., and McAvoy, R. 2012. Partial saturation under ebb and flow irrigation suppresses Pythium root rot of ornamentals. Crop Prot. 33:29-33.

Hancock, J. 1990. Colonization of rootlets of alfalfa by species of Pythium in relation to soil moisture. Phytopathology 80:1317-1322.

Jeffers, S., and Martin, S. 1986. Comparison of two media selective for Phytophthora and Pythium species. Plant Dis. 70:1038-1043.

Kim, J., van Iersel, M. W., and Burnett, S. E. 2011. Estimating daily water use of two petunia cultivars based on plant and environmental factors. HortScience 46:1287-1293.

Lea-Cox, J. D., Bauerle, W. L., van Iersel, M. W., Kantor, G. F., Bauerle, T. L., Lichtenberg, E., King, D. M., and Crawford, L. 2013. Advancing wireless sensor networks for irrigation management of ornamental crops: An overview. HortTechnology 23:717-724.

Lookabaugh, E. C., Ivors, K. L., and Shew, B. B. 2015. Mefenoxam sensitivity, aggressiveness, and identification of Pythium species causing root rot on floriculture crops in North Carolina. Plant Dis. 99:1550-1558.

Martin, F. N., and Loper, J. E. 1999. Soilborne plant diseases caused by Pythium spp.: ecology, epidemiology, and prospects for biological control. Crit. Rev. Plant Sci. 18:111-181.

Martinez-Espinoza, A. 2013. Georgia plant disease loss estimates. Coop. Ext.. Publ. AP 102-6, Univ. of Georgia, Tifton. http://extension.uga.edu/publications/ files/pdf/AP\%20102-6_1.PDF

Moorman, G., Kang, S., Geiser, D., and Kim, S. 2002. Identification and characterization of Pythium species associated with greenhouse floral crops in Pennsylvania. Plant Dis. 86:1227-1231.
Nemali, K. S., and van Iersel, M. W. 2006. An automated system for controlling drought stress and irrigation in potted plants. Sci. Hortic. (Amsterdam) 110:292-297.

Schlub, R. L., and Lockwood, J. 1981. Etiology and epidemiology of seedling rot of soybean by Pythium ultimum. Phytopathology 71:134-138.

Schoeneweiss, D. F. 1978. Water stress as a predisposing factor in plant disease. Pages 1-52 in: Water Deficits and Plant Growth. Academic Press, Amsterdam, The Netherlands.

Stanghellini, M., and Burr, T. 1973. Effect of soil water potential on disease incidence and oospore germination of Pythium aphanidermatum. Phytopathology 63:1496-1498.

Sterne, R. E., Zentmyer, G. A., and Kaufmann, M. R. 1977. The influence of matric potential, soil texture, and soil amendment on root disease caused by Phytophthora cinnamomi. Phytopathology 67:1495-1500.

UCLA-EEB. 2004. DNA extraction: Detailed chelex extraction protocol. Barber Ecology and Evolutionary Biology Laboratory, Dept. of Ecology and Evolutionary Biol. Univ. of Calif., Los Angeles. https://www.eeb.ucla.edu/ Faculty/Barber/Web\%20Protocols/Protocol2.pdf

van Iersel, M., Seymour, R. M., Chappell, M., Watson, F., and Dove, S. 2009. Soil moisture sensor-based irrigation reduces water use and nutrient leaching in a commercial nursery. Proc. Southern Nursery Assn. Res. Conf. 54:17-21.

White, T. J., Bruns, T., Lee, S., and Taylor, J. 1990. Amplification and direct sequencing of fungal ribosomal RNA genes for phylogenetics. Pages 315-322 in: PCR Protocols: A Guide to Methods and Applications. M. A. Innis, D. H. Gelfand, J. J. Sninsky, and T. J. White, eds. Academic Press, New York.

Wilcox, W., and Mircetich, S. 1985. Influence of soil water matric potential on the development of Phytophthora root and crown rots of Mahaleb cherry. Phytopathology 75:648-653. 